\title{
PERSONNEL SELECTION METHODS AND THE EMPLOYEE'S LABOUR MARKET
}

\author{
Olga ZWARDOŃ-KUCHCIAK ${ }^{1 *}$, Agnieszka LIPIŃSKA-GROBELNY² \\ ${ }^{1}$ Institute of Psychology, Department of Work and Organisational Psychology, University of Lódź; \\ olga.zwadon@uni.lodz.pl, ORCID: 0000-0001-8463-0496 \\ ${ }^{2}$ Institute of Psychology, Department of Work and Organisational Psychology, University of Lódź; \\ agnieszka.lipinska@uni.lodz.pl, ORCID: 0000-0003-2770-172 \\ * Correspondence author
}

\begin{abstract}
The aim of the study was to present a comparative analysis of personnel selection methods with the participation of two key groups in the recruitment process: recruiters and candidates. A multidimensional assessment was performed of the following selection tools: interview, application forms, personal questionnaires, psychological testing, knowledge tests, work samples, Assessment Centre (AC) and candidate screening. The study included 193 people aged between 20 and 55 years. Of these, 84 were HR professionals, and 109 were candidates for positions. The subjects assessed the personnel selection methods using a proprietary tool based on semantic differential. The obtained results indicate that the candidates and recruiters differed in their assessment of the methods. The recruiters considered the $\mathrm{AC}$, personal questionnaire, psychological tests and knowledge tests as the most effective, followed by work samples and candidate screening, with the application forms and interview as the least effective. In contrast, the candidates rated the interview the most highly, followed by application forms, candidate screening, work samples, psychological tests and knowledge tests, with personal questionnaires and AC the lowest. Summarising, research and practice in the field of HR needs to take into considerations macro issues (examining HR system more broadly), as well as micro issues (examining individual differences and perception).
\end{abstract}

Keywords: recruitment and selection, personnel selection methods, recruiters, candidates, employee's labour market.

\section{Introduction}

The past 10 years has seen a dramatic increase in the demand for workers in response to continual growth in the global economy (Barometer of employment prospects, 2018). Moreover, prognoses suggest that this demand may grow, with a very high requirement for employees. Of the labour markets in the EMEA area, the Polish market is regarded as being the fifth easiest regarding employment (Barometer of employment prospects, 2019). Hence, it would be fair to state that the current labour market is one for employees, as it is the job 
seekers who decide which advert to respond to and in which job to remain. Therefore, firms have taken steps to encourage applications from unemployed candidates and workers at other firms by investing in more refined recruitment strategies and in "recruiting with class". The latter means a focus on the customer, a two-way flow of information and the regular assessment of personnel selection methods from the macro HR perspective and the micro candidate's perspective. All these activities are designed to create an attractive image of an employer.

As it is shown form the meta-analysis by Chapman et al. (2005), the attractiveness of an employer correlates with the perception of the job (i.e. bonuses, type of work), of the organisation (i.e. its brand, reputation, location) and of the recruitment and selection process (i.e. recruiter's behaviour, choice of HR methods).

With this in mind, the aim of the present study was to introduce a comparative analysis of personnel selection methods with the participation of two key groups: recruiters and candidates. Firstly, the obtained knowledge fits with the idea of supporting business practice through science; secondly, it gains a greater understanding of the expectations of the two parties, which can lead to the better design of recruitment programmes and identification of the most effective methods of personnel selection.

\section{Methods of personnel selection and the employee's labour market}

The review will begin by defining the concept of personnel selection. Witkowski (2007) regards selection as essentially being of a social and bidirectional nature: on the one hand, an organisation makes a decision to submit a job offer to a candidate, while on the other, the candidate decides whether to accept it. In the institutional context, personnel selection is defined as a set of actions taken to fill a position so as to guarantee the continuity and efficiency of the organisation (Marek, 2008). During this process, it is important to adjust the competences of the candidate to the requirements of the workplace. To achieve this, a specific method of personnel selection is needed, i.e. one that enables the organisation to verify the professional suitability of its potential employees (Cowling, 2000; Kawka, \& Listwan, 2004). Accordingly, the method of personnel selection is understood as any form of activity that allows the selection of the best candidate for performing the tasks associated with a given position (Suchar, 2008).

Declining unemployment, difficulties in finding candidates and dynamic changes in competence requirements represent a real challenge for all business owners, bearing in mind that retention is now an everyday occurrence. McKinsey reports that while a typical period of employment in one organisation in the 1950s was longer than 23 years, this is now around 4 years. In addition, the costs of recruitment and induction are continually rising. For this reason, the labour market requires that not only do candidates need to be identified and 
contacted, but their professional competences also need to be verified using personnel selection methods. In addition, potential candidates may sometimes be discouraged from applying for a position due to the fear of the recruitment procedure; however, it is possible to increase the chances of their participation by including them in the recruitment and selection process. Another advantage of this approach is that such activities may also serve to build a positive image and brand for the employer (Backhaus, and Tikoo, 2004).

Backhaus and Tikoo (2004) propose that building such an image and brand confers a competitive advantage by emphasising the attractiveness of the organisation and the productivity of its employees. In this model, the actions undertaken as part of such employer branding are used to shape two assets: 1) the attractiveness of the organisation to external stakeholders and 2) loyalty to the employer's brand, resulting from the identity and culture of the organisation and the productivity of its employees (internal stakeholders). It should be assumed that the relations in question are bilateral, i.e. strengthening the employer brand increases the attractiveness and efficiency of the job, and conversely, these individual components can also support brand building. Hence, the methods chosen for personnel selection, i.e. striving for excellence in the process of acquiring staff, can be a source of benefits for current and potential employees and contribute to creating a strong employer brand.

Following previous studies regarding the frequency of use of selection tools (Dale, 2013; Jarecki, 2012; Marek, 2008; Witkowski, 2007; Wood, \& Payne, 2006), the following methods of staff selection were chosen for evaluation in the present study: 1) interview, 2) application form, 3) personal questionnaire, 4) psychological tests, 5) knowledge tests, 6) practical tests (work samples), 7) Assessment Centre (AC) and 8) candidate screening. Due to the fact that the selection of appropriate tools may determine the success of recruitment and even support the reputation of the employer, a number of studies have endeavoured to identify which method is regarded as the most effective.

\section{The aim of the study}

In the light of these issues, the theme of the study was to present a comparative analysis of the perceived effectiveness of chosen methods of personnel selection with the participation of both recruiters and potential employees. Although literature is rich in works evaluating selection tools with various criteria and groups of assessors, most studies examine the predictive validity of the methods (Armstrong, 2007; Cowling, 2000; Sajkiewicz, 1999; Witkowski, 2007) or the frequency of their application (Furnham, 2008; Lichtarski, 2007; Witkowski, 2007).

A meta-analysis of studies by Hunter and Schmidt on the methods of personnel recruitment (1990 by Lipińska-Grobelny, 2010) found that practical tests and special ability tests, Assessment Centre, cognitive tests (general intelligence) and a biographical questionnaire were 
generally regarded as being the most accurate forms of testing. In contrast, interview and personality testing appear to be characterised by a moderate degree of reliability and accuracy by many professional fields, while references and graphology are believed to provide the least reliable information about the candidate. Some interesting conclusions were reached in a survey of 255 specialists in personnel departments ( $52 \%$ women and $48 \%$ men), mainly employees of large British companies, regarding methods of assessing job candidates. The results indicate that the recruiters regarded the Assessment Centre (14.9\%), cognitive tests (13.9\%) and work samples $(13.6 \%)$ as the most accurate methods of personnel selection, while recommendations $(10.8 \%)$, references $(9.6 \%)$ and biographical questionnaire $(7.8 \%)$ were rated lowest (Furnham, 2008). A study of workers dealing with candidate selection also found the most common, and often the only, selection method to be the traditionally-conducted interview, being indicated in $66 \%$ of cases; less popular were the knowledge and skills tests (25\%), Assessment Centre $(19 \%)$, application analysis $(16 \%)$, with case study (2\%) and personal questionnaire (1\%) being the least commonly used (Chirkowska-Smolak \& Grobelny, 2014).

However, while Chirkowska-Smolak et al. (2014) or Furnham (2008) only evaluated recruiters, the present study surveys two groups involved in the selection process: recruiters and candidates. Additionally, in order to operationalise the concept of effectiveness, the current research examines the respondents concerning features which the most effective selection tools should possess, rather than using only single evaluation criteria (a frequency or the overall assessment of effectiveness). In this scrutiny, seven adjectives were selected, these being helpful, fair, multifaceted, effective, valid (in the sense of returning results that can be acted upon), reliable and non-schematic. They will be described more fully below. These adjectives were then used as sub-dimensions of effectiveness in the preparation of an original tool based on the semantic differential. It should be emphasised that this multidimensional approach was intended as a contrast to the single-dimension approach used in previous studies. Thus, the first research question was formulated:

Q1. Is there a difference between recruiters and candidates with regard to their assessment of personnel selection methods, with reference to the following dimensions: 1.1. helpful in making personnel decisions; 1.2. fair; 1.3. multifaceted; 1.4. effective; 1.5. valid; 1.6. reliable; 1.7. non-schematic?

The second research question was proposed in response to the possibility of comparison with other single-dimension surveys.

Q2. Is there a difference between recruiters and candidates in their assessment of the overall effectiveness of particular personnel selection methods? 


\section{Materials and Methods}

\subsection{Study group}

The study included 193 respondents aged 20 to $55(M=28, S D=7.17)$, including 84 recruiters $(\mathrm{R})$ and 109 candidates $(\mathrm{C})$. The analyses were carried out in accordance with the principles given in the Helsinki Declaration. The respondents were informed that their participation was voluntary, they were fully informed about the purpose and course of the study, and they were assured of their anonymity and the fact that the results would only be used for group analyses. The group of recruiters included 84 respondents (49 women and 35 men) aged 21 to 54 years $(M=30.2, S D=6.5)$, whose seniority in the position did not exceed ten years. Of this group, $94 \%$ were employees of personnel departments, while the remaining $6 \%$ were individuals influencing the personnel policy of a firm, i.e. company owners, directors or board members. In this group, all respondents had completed higher education, with the most frequently declared fields of study being Psychology (43\%), Human Resources Management and Pedagogy (30\%). The second group comprised 109 candidates seeking employment (70 women and 39 men) aged 20 to 55 years $(M=30.1, S D=7.6)$, of whom $45 \%$ had participated in at least five recruitment processes. Of this group, $65 \%$ had completed higher education, and $32 \%$ only secondary education.

\subsection{Employed study tools}

To address the study questions, a proprietary tool based on Osgood's semantic differential technique was used to quantitatively assess the content. The judgment-making procedure consists of placing the subject of the study, i.e. a specific selection method, on an empirical continuum determined by a pair of opposing adjectives (e.g. effective-ineffective). These individual continua form sub-dimensions that define the semantic space, within which the meaning of the tested concept is located. In addition, the scales used in the tool are strongly correlated with each other, thus forming a correlation bundle, i.e. a single dimension, which can be used to indicate overall assessment of effectiveness (Osgood, Suci, and Tannenbaum, 1957). The semantic differential prepared for the needs of the study was based on a five-point scale of responses for each of the seven sub-dimensions of the effectiveness of personnel selection methods given earlier. These were:

- helpful vs. unhelpful in making a decision about employment - the method largely supports the selection of the candidate and allows the assessor to fully present the desired competences;

- fair vs. unfair - the method allows reliable assessments to be made and minimises unfairness in the process of making personnel decisions; 
- multifaceted vs. single-aspect - the method allows a wide range of candidate potential to be checked;

- effective vs. ineffective - the method allows the selection of a candidate whose competences are best suited to the needs of the job;

- valid vs. invalid - the use of a specific method allows for objective measurement of the competences under test and gives measurable results;

- reliable vs. unreliable - the method is a good way of measuring what it has been intended for and guarantees measurement repeatability when re-used;

- non-schematic vs. schematic - the recruiter does not need to adhere to a specific procedure for testing with the given method.

The reliability of the tool was evaluated separately in the recruiter and candidate groups using Cronbach's alpha internal consistency method. The coefficients are presented in Tables 1-2. The obtained results indicate that the semantic differential for each of the eight methods of personnel selection in the candidate group was highly coherent, ranging from 0.94 to 0.99 . The results in the recruiter group were satisfactory, although more varied (0.56-0.86). Overall, across the whole group of 193 respondents, Cronbach's alpha found a satisfactory internal consistency (from 0.9 to 0.99 ).

Table 1.

Cronbach's alpha coefficients for the semantic differential for each studied personnel selection method (recruiters, $N=84$ )

\begin{tabular}{|c|c|c|c|c|c|c|c|c|}
\hline & Interview & $\begin{array}{c}\text { Application } \\
\text { form }\end{array}$ & $\begin{array}{c}\text { Personal } \\
\text { questionnaire }\end{array}$ & $\begin{array}{c}\text { Psychologi } \\
\text { cal tests }\end{array}$ & $\begin{array}{c}\text { Knowledge } \\
\text { tests }\end{array}$ & $\begin{array}{c}\text { Work } \\
\text { samples }\end{array}$ & $\begin{array}{c}\text { Assessment } \\
\text { Centre }\end{array}$ & $\begin{array}{c}\text { Candidate } \\
\text { screening }\end{array}$ \\
\hline $\begin{array}{c}\text { Cronbach's } \\
\text { alpha }\end{array}$ & 0.64 & 0.74 & 0.56 & 0.78 & 0.71 & 0.79 & 0.86 & 0.86 \\
\hline
\end{tabular}

Table 2.

Cronbach's alpha coefficients for the semantic differential for each studied personnel selection method (candidates, $N=109$ )

\begin{tabular}{|c|c|c|c|c|c|c|c|c|}
\hline & Interview & $\begin{array}{c}\text { Application } \\
\text { form }\end{array}$ & $\begin{array}{c}\text { Personal } \\
\text { questionnaire }\end{array}$ & $\begin{array}{c}\text { Psychologi } \\
\text { cal tests }\end{array}$ & $\begin{array}{c}\text { Knowledge } \\
\text { tests }\end{array}$ & $\begin{array}{c}\text { Work } \\
\text { samples }\end{array}$ & $\begin{array}{c}\text { Assessment } \\
\text { Centre }\end{array}$ & $\begin{array}{c}\text { Candidate } \\
\text { screening }\end{array}$ \\
\hline $\begin{array}{c}\text { Cronbach's } \\
\text { alpha }\end{array}$ & 0.94 & 0.95 & 0.97 & 0.97 & 0.97 & 0.98 & 0.99 & 0.98 \\
\hline
\end{tabular}

\section{Results}

The tables present the results of the non-parametric Mann-Whitney $U$-test for independent samples and the size of the obtained effect as a rank-biserial correlation coefficient according to Glass $\left(r_{\mathrm{g}}\right)$. The first part of this section addresses the first research question, i.e. do recruiters and candidates vary in their assessment of the chosen personnel selection methods, with respect to the following dimensions: helpful (in making personnel decisions), fair, multifaceted, effective, valid, reliable and non-schematic. 
The data contained in Table 3 and 4 reveals that the interview and application forms differed significantly for all tested sub-dimensions $\left(\mathrm{U}_{1}\right.$ to $\left.\mathrm{U}_{6}\right)$ apart from non-schematic $\left(\mathrm{U}_{7}\right)$, with the recruiters awarding higher mean rank scores for the other six sub-dimensions. For the interview, small effects $\left(r_{g}=0.1\right)$ were observed for validity, effective, reliable, fairness and helpful. Only multifaceted achieved a moderate effect $\left(r_{g}=0.36\right)$. Similarly, the application forms were found to have a weak effect for most sub-dimensions (effective, valid, reliable, fair, non-schematic). None of the effects were found to have high values. Multifaceted and helpful were characterised by moderate results.

Table 3.

Comparative analysis of the seven sub-dimensions for the interview, application forms, personal questionnaire and psychological tests

\begin{tabular}{|c|c|c|c|c|c|c|c|c|}
\hline & \multicolumn{2}{|c|}{ Interview } & \multicolumn{2}{|c|}{ Application form } & \multicolumn{2}{|c|}{$\begin{array}{c}\text { Personal } \\
\text { questionnaire }\end{array}$} & \multicolumn{2}{|c|}{ Psychological tests } \\
\hline & $\begin{array}{c}\text { Mann- } \\
\text { Whitney } \\
\text { U-test }\end{array}$ & $r_{g}$ & $\begin{array}{c}\text { Mann- } \\
\text { Whitney } \\
\text { U-test }\end{array}$ & $r_{g}$ & $\begin{array}{c}\text { Mann- } \\
\text { Whitney } \\
\text { U-test }\end{array}$ & $r_{g}$ & $\begin{array}{c}\text { Mann- } \\
\text { Whitney } \\
\text { U-test }\end{array}$ & $r_{g}$ \\
\hline Helpful (1) & $3,480.5 * *$ & 0.23 & $2,955.5 * * *$ & 0.35 & $2,309 * * *$ & 0.5 & $2,592.5 * * *$ & 0.43 \\
\hline Fair (2) & $3,585 * *$ & 0.21 & $3,356.5 * * *$ & 0.26 & $2,530.5 * * *$ & 0.45 & $2,630.5 * * *$ & 0.43 \\
\hline Multifaceted (3) & $2,926.5 * * *$ & 0.36 & $3,202.5 * * *$ & 0.30 & $2,593 * * *$ & 0.43 & $2,531.5 * * *$ & 0.45 \\
\hline Effective (4) & $3822 * *$ & 0.16 & $3,618 * *$ & 0.21 & $2,273.5 * * *$ & 0.5 & $2,471.5 * * *$ & 0.46 \\
\hline Valid (5) & $3,863.5 * *$ & 0.15 & $3,563.5^{* *}$ & 0.22 & $2,357.5 * * *$ & 0.48 & $2,266 * * *$ & 0.5 \\
\hline Reliable (6) & $3,771.5 * *$ & 0.17 & $3,475.5 * *$ & 0.24 & $2,119.5 * * *$ & 0.54 & $2,501 * * *$ & 0.45 \\
\hline Non-schematic (7) & 4,568 & 0 & 4,341 & 0.05 & $2,948 * * *$ & 0.36 & $2,559.5 * * *$ & 0.44 \\
\hline
\end{tabular}

Note: $\mathrm{p}<0.05^{*} ; \mathrm{p}<0.01^{* *} ; \mathrm{p}<0.001^{* * *}$

$r_{g}-0.1$ - small effect; $r_{g}-0.3$ - moderate effect; $r_{g}-0.5$ - large effect

Table 4.

Mean rank score for the seven sub-dimensions for the interview, application form, personal questionnaire and psychological tests

\begin{tabular}{|l|c|c|c|c|c|c|c|c|}
\hline \multirow{2}{*}{} & \multicolumn{2}{|c|}{ Interview } & \multicolumn{2}{c|}{ Application form } & \multicolumn{2}{c|}{$\begin{array}{c}\text { Personal } \\
\text { questionnaire }\end{array}$} & \multicolumn{2}{c|}{ Psychological tests } \\
\cline { 2 - 10 } & Recruiter & Candidate & Recruiter & Candidate & Recruiter & Candidate & Recruiter & Candidate \\
\hline Helpful (1) & $\mathbf{1 1 0 . 0 7}$ & 86.93 & $\mathbf{1 1 6 . 3 2}$ & 82.11 & $\mathbf{1 2 4 . 0 1}$ & 76.18 & $\mathbf{1 2 0 . 6 4}$ & 78.78 \\
\hline Fair (2) & $\mathbf{1 0 8 . 8 2}$ & 87.89 & $\mathbf{1 1 1 . 5 4}$ & 85.79 & $\mathbf{1 2 1 . 3 8}$ & 78.22 & $\mathbf{1 2 0 . 1 8}$ & 79.13 \\
\hline $\begin{array}{l}\text { Multifaceted } \\
\text { (3) }\end{array}$ & $\mathbf{1 1 6 . 6 6}$ & 81.85 & $\mathbf{1 1 3 . 3 8}$ & 84.38 & $\mathbf{1 2 0 . 6 3}$ & 78.79 & $\mathbf{1 2 1 . 3 6}$ & 78.22 \\
\hline Effective (4) & $\mathbf{1 0 6 . 0}$ & 90.06 & $\mathbf{1 0 8 . 4 3}$ & 88.19 & $\mathbf{1 2 4 . 4 3}$ & 75.86 & $\mathbf{1 2 2 . 0 8}$ & 77.67 \\
\hline Valid (5) & $\mathbf{1 0 5 . 5 1}$ & 90.44 & $\mathbf{1 0 9 . 0 8}$ & 87.69 & $\mathbf{1 2 3 . 4 3}$ & 76.63 & $\mathbf{1 2 4 . 5 2}$ & 75.79 \\
\hline Reliable (6) & $\mathbf{1 0 6 . 6 0}$ & 89.60 & $\mathbf{1 1 0 . 1 3}$ & 86.89 & $\mathbf{1 2 6 . 2 7}$ & 74.44 & $\mathbf{1 2 1 . 7 3}$ & 77.94 \\
\hline $\begin{array}{l}\text { Non- } \\
\text { schematic } \\
\text { (7) }\end{array}$ & 96.88 & 97.09 & 99.82 & 94.83 & $\mathbf{1 1 6 . 4 0}$ & 82.05 & $\mathbf{1 2 1 . 0 3}$ & 78.48 \\
\hline
\end{tabular}

The Mann-Whitney $U$-test revealed significant differences between recruiters and candidates regarding the seven dimensions of the personal questionnaire and those of the psychological tests (Tables 3-4). Again, the recruiters tended to assign higher grades to the individual sub-dimensions for the personal questionnaire and psychological tests than the candidates. The effect sizes of the dimensions for the personal questionnaire were: moderate $\left(r_{g}=0.3\right)$ for non-schematic, multifaceted, fair, valid; or high $\left(r_{g}=0.5\right)$ for helpful, effective, reliable. Those of the psychological tests were similar, with moderate values observed for 
helpful, fair, non-schematic, reliable, multifaceted and effective. The only high effect was observed for valid.

When analysing the results given in Table 5 and 6 , it is important to note that significantly different scores were awarded by recruiters and candidates for all tested sub-dimensions of knowledge tests and practical exercises (work samples). Significantly higher results were obtained from the group of recruiters. In most cases, the size of the effect was moderate $\left(r_{g}=0.3\right)$ : non-schematic, valid, effective, multifaceted, reliable and fair for the knowledge tests; and fair, valid, multifaceted and effective for the practical exercises. A large effect $\left(r_{g}=0.5\right)$ was observed for helpful for knowledge tests and practical exercises, as well as for reliable for practical exercises.

\section{Table 5.}

Comparison of knowledge tests, practical exercises (work samples), Assessment Centre and candidate screening in terms of the seven sub-dimensions

\begin{tabular}{|c|c|c|c|c|c|c|c|c|}
\hline & \multicolumn{2}{|c|}{ Knowledge tests } & \multicolumn{2}{|c|}{ Work samples } & \multicolumn{2}{|c|}{ Assessment Centre } & \multicolumn{2}{|c|}{ Candidate screening } \\
\hline & $\begin{array}{c}\text { Mann- } \\
\text { Whitney } \\
\text { U-test }\end{array}$ & $r_{g}$ & $\begin{array}{c}\text { Mann- } \\
\text { Whitney } \\
\text { U-test }\end{array}$ & $r_{g}$ & $\begin{array}{c}\text { Mann- } \\
\text { Whitney } \\
\text { U-test }\end{array}$ & $r_{g}$ & $\begin{array}{c}\text { Mann- } \\
\text { Whitney } \\
\text { U-test }\end{array}$ & $r_{g}$ \\
\hline Helpful (1) & $2,145 * * *$ & 0.5 & $2,027 * * *$ & 0.56 & $1,617 * * *$ & 0.65 & $2,826 * * *$ & 0.38 \\
\hline Fair (2) & $2,331 * * *$ & 0.49 & $2,651.5 * * *$ & 0.42 & $2,011 * * *$ & 0.56 & $3,775 * *$ & 0.17 \\
\hline Multifaceted (3) & $2,490 * * *$ & 0.46 & $2,397.5 * * *$ & 0.48 & $1,844.5 * * *$ & 0.6 & $3,263.5 * * *$ & 0.29 \\
\hline Effective (4) & $2,527.5 * * *$ & 0.45 & $2,342 * * *$ & 0.49 & $1,877 * * *$ & 0.59 & $3,128.5 * * *$ & 0.32 \\
\hline Valid (5) & $2,926.5 * * *$ & 0.36 & $2,608.5 * * *$ & 0.43 & $2,118.5 * * *$ & 0.54 & $3,605 * *$ & 0.21 \\
\hline Reliable (6) & $2,402 * * *$ & 0.47 & $1,905 * * *$ & 0.58 & $1,827.5 * * *$ & 0.6 & $2,926 * * *$ & 0.36 \\
\hline Non-schematic (7) & $2,987 * * *$ & 0.35 & $3,733 *$ & 0.18 & $1,993.5 * * *$ & 0.56 & $3,006.5 * * *$ & 0.34 \\
\hline
\end{tabular}

Note: $\mathrm{p}<0.05^{*} ; \mathrm{p}<0.01^{* *} ; \mathrm{p}<0.001^{* * *}$

$r_{g}-0.1$ - small effect; $r_{g}-0.3$ - moderate effect; $r_{g}-0.5$ - large effect

Table 6.

Mean rank values for knowledge tests, practical exercises (work samples), Assessment Centre and candidate screening in terms of the seven tested sub-dimensions

\begin{tabular}{|l|c|c|c|c|c|c|c|c|}
\hline & \multicolumn{2}{|c|}{ Knowledge tests } & \multicolumn{2}{c|}{ Work samples } & \multicolumn{2}{c|}{ Assessment Centre } & \multicolumn{2}{c|}{ Candidate screening } \\
\cline { 2 - 9 } & Recruiter & Candidate & Recruiter & Candidate & Recruiter & Candidate & Recruiter & Candidate \\
\hline Helpful (1) & $\mathbf{1 2 5 . 9 6}$ & 74.68 & $\mathbf{1 2 7 . 3 7}$ & 73.60 & $\mathbf{1 3 2 . 2 5}$ & 69.83 & $\mathbf{1 1 7 . 8 6}$ & 80.93 \\
\hline Fair (2) & $\mathbf{1 2 3 . 7 5}$ & 76.39 & $\mathbf{1 1 9 . 9 3}$ & 79.33 & $\mathbf{1 2 7 . 5 6}$ & 73.45 & $\mathbf{1 0 6 . 5 6}$ & 89.63 \\
\hline $\begin{array}{l}\text { Multifaceted } \\
\text { (3) }\end{array}$ & $\mathbf{1 2 1 . 8 6}$ & 77.84 & $\mathbf{1 2 2 . 9 6}$ & 77.00 & $\mathbf{1 2 9 . 5 4}$ & 71.92 & $\mathbf{1 1 2 . 6 5}$ & 84.94 \\
\hline Effective (4) & $\mathbf{1 2 1 . 4 1}$ & 78.19 & $\mathbf{1 2 3 . 6 2}$ & 76.49 & $\mathbf{1 2 9 . 1 5}$ & 72.22 & $\mathbf{1 1 4 . 2 6}$ & 83.70 \\
\hline Valid (5) & $\mathbf{1 1 6 . 6 6}$ & 81.85 & $\mathbf{1 2 0 . 4 5}$ & 78.93 & $\mathbf{1 2 6 . 2 8}$ & 74.44 & $\mathbf{1 0 8 . 5 8}$ & 89.07 \\
\hline Reliable (6) & $\mathbf{1 2 2 . 9 0}$ & 77.04 & $\mathbf{1 2 8 . 8 2}$ & 72.48 & $\mathbf{1 2 9 . 7 4}$ & 71.77 & $\mathbf{1 1 6 . 6 7}$ & 81.84 \\
\hline $\begin{array}{l}\text { Non-schematic } \\
\text { (7) }\end{array}$ & $\mathbf{1 1 5 . 9 4}$ & 82.40 & $\mathbf{1 0 7 . 0 6}$ & 89.25 & $\mathbf{1 2 7 . 7 7}$ & 73.29 & $\mathbf{1 1 5 . 7 1}$ & 82.58 \\
\hline
\end{tabular}

Finally, significant differences were observed between the two tested groups with regard to their evaluation of the final two assessment tools, i.e. the Assessment Centre and candidate screening. As with the previous tools, these two were rated more highly by the group of recruiters. The effect size for the Assessment Centre was large $\left(r_{g}=0.5\right)$ for all tested subdimensions, i.e. helpful, fair, multifaceted, effective, valid, reliable and non-schematic. Regarding the candidate screening, effective, non-schematic, reliable and helpful demonstrated 
moderate effect sizes $\left(r_{g}=0.3\right)$, while fair, valid and multifaceted were small $\left(r_{g}=0.1\right)$ (Tables 5-6).

The second study question compared the evaluation of recruiters and candidates with regard to their overall assessment of the effectiveness of the selection tool, this being the resultant of the seven dimensions of the semantic differential. As can be seen in Table 7, the two groups gave different evaluations for interview, application form, personal questionnaire, and for psychological testing, knowledge test, work samples, Assessment Centre and candidate screening. Small effect sizes were observed for interview, application form and candidate screening, with a moderate effect for practical exercises (work samples), knowledge test and psychological testing. Two tools demonstrated large effect sizes: personal questionnaire and Assessment Centre.

Recruiters considered the Assessment Centre to be the most effective method, followed by the personal questionnaire, psychological testing and knowledge tests, then followed by practical exercises (work samples), candidate screening and, finally, application forms and interview. In contrast, the candidates rated the interview the highest, followed by the application documents, candidate screening, practical exercises (work samples), psychological testing and knowledge tests, with the personal questionnaire and $\mathrm{AC}$ being rated the lowest.

\section{Table 7.}

Comparison of all personnel selection tools with regard to their overall effectiveness

\begin{tabular}{|l|c|c|c|c|}
\hline & Mann- Whitney U-test & $\boldsymbol{r}_{\boldsymbol{g}}$ & $\boldsymbol{M}_{\boldsymbol{R}}$ & $\boldsymbol{M}_{\boldsymbol{C}}$ \\
\hline Interview & $\mathbf{3 , 7 0 8 . 5 *}$ & 0.19 & $\mathbf{1 0 7 . 3 5}$ & 89.02 \\
\hline Application form & $\mathbf{3 , 4 9 7 . 5 *}$ & 0.24 & $\mathbf{1 0 9 . 8 6}$ & 87.09 \\
\hline Personal questionnaire & $\mathbf{2 , 2 9 6 . 0 * * *}$ & 0.5 & $\mathbf{1 2 4 . 1 7}$ & 76.06 \\
\hline Psychological tests & $\mathbf{2 , 4 1 1 . 5 * * *}$ & 0.47 & $\mathbf{1 2 2 . 7 9}$ & 77.12 \\
\hline Knowledge tests & $\mathbf{2 , 4 6 8 . 5 * * *}$ & 0.46 & $\mathbf{1 2 2 . 1 1}$ & 77.65 \\
\hline Work samples & $\mathbf{2 , 6 7 7 . 5 * * *}$ & 0.42 & $\mathbf{1 1 9 . 6 3}$ & 79.56 \\
\hline Assessment Centre & $\mathbf{2 , 0 7 3 . 5 * * *}$ & 0.55 & $\mathbf{1 2 6 . 8 2}$ & 74.02 \\
\hline Candidate screening & $\mathbf{3 , 3 4 3 . 5 * * *}$ & 0.27 & $\mathbf{1 1 1 . 7 0}$ & 85.67 \\
\hline
\end{tabular}

Note: $\mathrm{p}<0.05^{*} ; \mathrm{p}<0.01^{* *} ; \mathrm{p}<0.001^{* * *}$

$r_{g}-0.1$ - small effect; $r_{g}-0.3$ - moderate effect; $r_{g}-0.5$ - large effect

\section{Discussion}

The objective of this research was to perform a comparative analysis of chosen personnel selection with the participation of two key groups: recruiters and candidates. The obtained knowledge fits with the idea of supporting business practice through science. Moreover, it gains a greater understanding of the expectations of the two parties, which can lead to the better design of recruitment programmes and identification of the most effective methods of personnel selection. In these times characterised by a job seekers' labour market, candidates expect not only access to job offers, but also a personalised approach to the recruitment process. Growing 
numbers of organisations are becoming aware of the importance of getting to know the experiences and impressions held by candidates, together with their evaluation of the recruitment process. Not only does this have an influence on the management of human resources in the organisation, but also on the public image of the company and its business effects. Negative impressions from the recruitment process can quickly be shared, thus tarnishing the image of the company and, more importantly, reducing interest among potential candidates.

The first research question (Q1.1.-Q1.7.), regarding whether the two groups of respondents differed in their assessment of individual methods of personnel selection, was confirmed. The recruiter group, i.e. the staff of the HR department and those responsible for steering the company HR policy, rated the interview, application forms, personal questionnaire, psychological testing, knowledge tests, work samples, Assessment Centre and candidate screening more highly than the candidates with regard to helpfulness in making personnel decisions, fairness, their multi-faceted nature, effectiveness, validity, reliability and nonschematic structure (with the exception of the interview and application forms). The magnitude of the effect ranged from medium to high. This more favourable evaluation by the recruiters may result from their more extensive knowledge about the effectiveness of the various selection tools and their wider experience of their use. In addition, their commitment may also have played a role, and this may adversely affect the selection of personnel selection methods.

An analysis of the seven individual sub-dimensions indicates that specialists considered the Assessment Centre to be the most helpful method in deciding upon staff, as well as being the fairest, most multifaceted, effective, valid, reliable and non-schematic tool. The recruiters also rated practical exercises and knowledge tests quite highly in terms of helpfulness, while the candidates preferred interview, application forms and candidate screening. In terms of fairness, the recruiters rated the Assessment Centre, knowledge tests and personal questionnaires the most highly, while the candidates preferred the candidate screening, interview and application forms as not only fair, but also superior in terms of being multi-faceted, effective, valid, reliable and non-schematic. The multidimensional analysis revealed that the recruiters ranked the Assessment Centre as being the most effective tool overall; however, practical exercises and interview were also awarded high scores for being multifaceted, personal questionnaire and practical exercises as being effective, psychological tests and personal questionnaire for validity, practical exercises and personal questionnaire for reliability, and psychological testing and knowledge tests were rated highly for being non-schematic.

Regarding the second question, the recruiters gave a more favourable assessment of overall effectiveness for some of the personnel selection tools. Interestingly, while the Assessment Centre (AC) was ranked most highly by recruiters, it was rated lowest by the candidates. The recruiters based their positive evaluation on its multidimensionality and its level of precision associated with its preparation and implementation. In addition, as the successful candidate can be equipped with the necessary hard skills for a post relatively quickly, employers 
tend to place more value on assessing soft skills during recruitment and thus place a high value on Assessment Centre evaluation during recruitment as a method of verifying behaviour in the workplace. Further confirmation of these high scores can be found in meta-analyses by J.E. Hunter and F.L. Schmidt (1990) (Lipińska-Grobelny, 2010) and A. Furnham (2008), which confirm the significance of the Assessment Centre. In turn, the candidates reacted negatively to the AC, due to the sophisticated method of research, lack of introductory information as to its purpose and the nature of the tasks being performed. In addition, the personal questionnaire and psychological testing were ranked much more highly by the recruiters than the candidates, and while the candidates regarded the interview, application form and candidate screening as the most effective tools, the recruitment group found the opposite. It is possible that the candidates have the highest regard for the methods with which they have the most contact; therefore, the perception of the $\mathrm{AC}$ among candidates and the procedures associated with it may be improved by regularly referring to the AC during recruitment.

The results obtained are quite surprising, as the specialists implementing the process of personnel selection have an entirely different perception of the selection tools as its main heroes, i.e. the candidates. The evaluations given by the recruiters are not surprising when considering their greater experience, knowledge and qualifications regarding the issue. They regard the most effective methods as those that are standardised with a clearly defined procedure and which offer clear recommendations for choosing the best candidate. However, it seems that specialists do not appreciate which methods are the most popular or which are used most frequently (Dale, 2013; Jarecki, 2012; Marek, 2008; Witkowski, 2007). In addition, our findings suggest they also do not favour the methods preferred by the candidates. The high scores awarded by candidates to traditional interviews and application forms may be associated with the high popularity and wide availability of these methods. The candidates may have knowledge regarding the theoretical and practical aspects of the methods which were used to test them. There could also be a contextual effect associated with the tools, where positive associations are activated by the experience, e.g. getting a job after a job interview. In addition, their positive evaluation of these methods may offer an insight into the nature of the labour market and may encourage candidates to take part in the recruitment and selection process. These methods are also the most commonly used by recruiters during the selection process (Chirkowska-Smolak \& Grobelny, 2014). Well-known methods, such as interviews or application forms, provide a sense of security for the candidates, and they guarantee preparedness and eliminate stress.

The role of the specialist is to create a personnel selection process to attract as many potential employees as possible and then to select those whose competences are best suited to the vacant position. As a well-chosen method can widen the pool of people taking part in the recruitment process, our present findings, and the dynamics of the labour market, emphasise the need to consider the opinion of the candidates regarding recruitment. However, while interviews and application forms have proven to be effective tools from the point of view of the 
candidate, recruiters should also further refine their use to suit their own needs. Well-structured interviews can achieve high efficiency, but the results depend on the content and form of the interview. The best solution for the two groups may lie within the structure of the tool, i.e. by choosing suitable questions for the interview and devising appropriate criteria for assessing the response. Topgrading, by Brad Smart, details an ideally prepared job interview, including behavioural, cognitive or situational questions with clearly defined assessment criteria, irrespective of the subjectivity of the recruiter.

\section{Summary, limitations and directions for future study}

Due to the pace of change in the modern world, we now live and work in a global village. One space for the exchange of experiences and competences is the labour market, which extended its borders outside Poland in 2004 upon its accession to the European Union. This event opened doors, not only for Polish specialists planning to work overseas, but also to corporations who had hitherto only been successful in Poland. The Polish economic landscape has undergone considerable changes in recent years, and these changes are particularly visible in the sphere of employment. Unemployment fell from $11.4 \%$ at the end of 2014 to $5.8 \%$ at the end of 2018. Many businesses, both Polish and foreign, which had not previously had problems with recruitment, now face the challenge of providing full staffing. For this reason, the opinions of both recruiters and job applicants on the effectiveness of personnel selection methods is of great importance, as they can have an important impact on recruitment practice facilitating successful employment (Woźniak, 2012, 2019).

According to the Directions 2017 report, the greatest investments on the Polish labour market are represented by companies from France, Germany, Spain and the United Kingdom. In addition, the latest Nielsen report, commissioned by CCI France Pologne (French-Polish Chamber of Commerce), 75\% of the French organisations surveyed regard Poland's investment attractiveness as positive or very positive and the competences of Polish employees as very high. However, they also rate employee availability on the labour market as very low. Hence, it is important that the recruitment and selection process is carried out efficiently to guarantee access to qualified staff. In addition, Polish companies are also becoming more attractive to foreign employees. According to the Ministry of Family, Labour and Social Policy, in 2017, approximately 250,000 work permits were issued to foreign workers, almost $100 \%$ higher than in 2016, and district labour offices registered approximately 1.8 million statements of intention to employ foreign workers from businesses: almost $40 \%$ higher (Employment of foreigners in Poland, 2018). In response to this growing interest in the Polish labour market, the personnel selection process should be open to new environments. In addition, a greater familiarity with preferred selection methods will allow potential foreign employees to be more prepared for 
interviews and to better understand the idiosyncrasies of the new market. Furthermore, the new environment brings new challenges regarding "distance recruitment", and with it, the use of ICT tools, which are regarded as being not as fair as traditional methods (Woźniak, 2019). From this perspective, employers facing a "talent shortage" would be advised to accommodate the preferences of candidates, as the use of an inappropriate method can lead to withdrawal from the entire selection process (Hausknecht, Day, \& Thomas, 2004; Truxillo \& Bauer, 2011).

Summarising, recruitment and selection are the key strategic domain in human resources management. As was mentioned, research and practice in the field of HR need to take into considerations macro issues (examining HR system more broadly), as well as micro issues (examining individual differences and apperception). In that research, both perspectives were included. What is well established is that candidates make inferences about companies based on how they are treated in the selection process (Chapman et al., 2005). Therefore, it is reasonable to further explore the opinions and needs of potential employees and how the recruitment and selection process can be used to shape a desirable brand for the employer. It is the people who choose to take part in the recruitment process who then apply for a position, and our present findings may indicate which selection tools are preferred by desirable employees. Another possible approach is the obtained knowledge that fits with the idea of supporting business practice through science, increasing professionalisation in the field of HRM. The authors are aware that the study has some limitations. Therefore, it is recommended that further studies should be performed involving larger groups of recruiters with matching groups of work positions, as this may offer a further insight into how the selection process should best be formulated. Future research should also adapt a multilevel perspective to display whether validities of selection methods at the individual level are associated with the organisational level.

\section{References}

1. Armstrong, M. (2007). Zarządzanie Zasobami Ludzki [Human Resource Management]. Kraków: Oficyna \& Wolters Kluwer Business.

2. Backhaus, K., and Tikoo, S. (2004). Conceptualizing and researching employer branding. Career Development International, 9, 5, 501-517, doi: 10.1108/13620430410550754.

3. Barometer of employment prospects 2018. Retrieved from http://www.manpowergroup.pl/ wpcontent/uploads/2017/12/Barometr_Manpower_Perspektyw_Zatrudnienia_Q1_18_PL _www.pdf, 10.10.2018.

4. Barometer of employment prospects 2019. Retrieved from https://www.manpowergroup. com/wps/wcm/connect/ec952d82-f46e-4502-a513d376cacf6278/PO_PO_1Q19_Release. pdf?, 2.01.2019. 
5. Chapman, D.S., Uggerslev, K.L., Carroll, S.A., Piasentin, K.A., and Jones, D.A. (2005). Applicant attraction to organizations and job choice: A meta-analytic review of correlates of recruiting outcome. Journal of Applied Psychology, 90, 5, 928-944, doi: 10.1037/00219010.90.5.928.

6. Chirkowska-Smolak, T., and Grobelny, J. (2014). Wykorzystanie metod doboru personelu oraz przekonania profesjonalistów na temat ich trafności prognostycznej [Use of personnel selection methods and the views of professionals regarding their predictive validity]. Zarzadzanie Zasobami Ludzkimi [Human Resource Management], 96, 1, 125-141.

7. Cowling, A. (2000). Strategiczne zarzadzanie zasobami ludzkimi [Strategic management of human resources]. Kraków: Oficyna Ekonomiczna.

8. Dale, M. (2013). Skuteczna rekrutacja i selekcja pracowników [Effective recruitment and selection of employees]. Kraków: Oficyna Ekonomiczna.

9. Directions 2017. Negative economic shocks. Stress-tests of the Polish economy in 2017, Retrieved from https://www.slideshare.net/DeloittePolska/raport-kierunki-2017negatywne-szoki-gospodarcze-stresstesty-polskiej-gospodarki-w-2017-r, 28.11.2019.

10. Employment of foreigners in Poland. Retrieved from https://psz.praca.gov.pl/rynekpracy/statystyki-i-analizy/zatrudnianie-cudzoziemcow-w-polsce, 3011.2019.

11. Furnham, A. (2008). HR Professionals' beliefs about, and knowledge of, assessment techniques and psychometric tests. International Journal of Selection and Assessment, 16, 3, 300-305, doi: 10.1111/j.1468-2389.2008.00436.x.

12. Hausknecht, J.P., Day, D.V., and Thomas, S.C. (2004). Applicant reactions to selection procedures: An updated model and meta-analysis. Personnel Psychology, 57, 639-683.

13. Hunter, J.E., and Hunter, R.F. (1984). Validity and utility of alternative predictors of job performance. Psychological Bulletin, 96, 1, 72-98, doi: 10.1037/0033-2909.96.1.72.

14. Jarecki, W. (2012). Rekrutacja pracowników [Recruitment of employees]. Szczecin: Economicus.

15. Kawka, T., and Listwan, T. (2004). Pozyskiwanie pracowników [Recruitment of employees]. In: T. Listwan (ed.), Zarzadzanie Zasobami Ludzkimi [Human Resources Management] (pp. 76-101). Warszawa: C.H. Beck.

16. Lichtarski, J.M. (2007). Specyfika doboru pracowników do struktur zadaniowych w teorii i praktyce [The specificity of selecting employees for task structures in theory and practice]. Zarzadzanie Zasobami Ludzkimi [Human Resource Management], 6, 25-40.

17. Lipińska-Grobelny, A. (2010). Rola testów psychologicznych w ocenie przydatności zawodowej kandydatów do pracy [The role of psychological tests in assessing the professional suitability of candidates for work]. In: Z. Goral (ed.), Kontrola pracownika. Możliwości techniczne i dylematy prawne [Employee control. Technical possibilities and legal dilemmas] (pp. 467-480). Warszawa: Wydawnictwo Wolters Kluwer. 
18. Marek, J. (2008). Pozyskiwanie $i$ dobór personelu: ksztaltowanie zatrudnienia w organizacji [Acquisition and selection of staff: shaping employment in the organization]. Warszawa: Difin.

19. Nielsen Report. 25 years of Polish-French partnership. French investments in Poland (2019). Retrieved from https://assets.kpmg/content/dam/kpmg/pl/pdf/pl-raport-kpmg-iccifp-25-lat-polsko-francuskiego-partnerstwa-pl.pdf, 2911.2019.

20. Osgood, C.E., Suci, D.J., and Tannenbaum P.H. (1957). The measurement of meaning. Urbana: University of Illinois Press.

21. Sajkiewicz, A. (1999). Zasoby ludzkie $w$ firmie [Human resources in the company]. Warszawa: Poltext.

22. Suchar, M. (2008). Rekrutacja i selekcja personelu [Recruitment and personnel selection]. Warszawa: C.H. Beck.

23. Truxillo, D. M., and Bauer, T. N. (2011). Applicant reactions to organizations and selection systems. In: S. Zedeck (ed.), APA handbooks in psychology. APA handbook of industrial and organizational psychology, 2. Selecting and developing members for the organization (pp. 379-397). Thousand Oaks, CA, Sage: American Psychological Association.

24. Witkowski, T. (2007). Nowoczesne metody doboru i oceny personelu [Modern methods of personnel selection and evaluation]. Kraków: Wydawnictwo Profesjonalnej Szkoły Biznesu.

25. Wood, R, Payne, T. (2006). Metody rekrutacji i selekcji pracowników oparte na kompetencjach [Methods of recruitment and selection of employees based on competences]. Kraków: Oficyna Ekonomiczna.

26. Woźniak, J. (2012). Współczesne systemy motywacyjne [Modern incentive systems]. Warszawa: PWN.

27. Woźniak, J. (2019). Akceptacja różnych form narzędzi selekcyjnych - przegląd literatury i wstępne wyniki badania [Fairness assessment of different forms of traditional and ICTbased selection tools: review of literature and first results of empirical study]. Zarzadzanie Zasobami Ludzkimi [Human Resource Management], 5, 11-37. 